between 1939 and 1940 from $77 \cdot 1$ per 100,000 to 87.4 ; for females the increase was 7 per cent from 50.9 to $54 \cdot 7$. In Scotland the deaths from tuberculosis in 1940 increased 14 per cent over 1939, and the death.rate in 1940 was the highest since 1932. In Canada the mortality from tuberculosis did not rise in 1940, but there was a signiticant increase for the first half of 1941. In Germany and the occupied countries statistics on tuberculosis are not available. As regards France, a sharp increase in the disease has been reported from Vichy. The longer the War lasts and the farther it extends the greater will be the increase in tuberculosis, as is shown by the War of 1914-18, particularly among the women and children in Germany, Belgium, and eastern and south-eastern Europe, and to a less degree among the neutral countries.

\section{Prevention of Typhus Fever}

AT a meeting of the Section of Epidemiology and State Medicine of the Royal Society of Medicine on November 28, Dr. Melville D. Mackenzie read a paper on the control of louse-borne typhus fever in Great Britain in the light of experience in Russia, Poland, Rumania and China. After discussing the epidemiological relationship of the disease to movements of population, under-nourishment and climatic conditions, he dealt with the rapidity of the spread of typhus fever, the frequency with which it is associated with other diseases and other factors which might complicate diagnosis, the method of infection, the importance of improved nutrition in the control of an epidemic, the value of reducing the number of lice in the population generally in addition to the tracing and delousing of contacts, the possible importance of dried fæces in the spread of the disease and the danger of the first cases being overlooked. Stress was laid on the necessity of utilizing young personnel in anti-typhus work. The greatest importance was attributed to the necessity for the thorough disinfestation of patients and contacts, the premises and their contents, as well as of the ambulance and the staff after duty.

\section{The National Institute for Research in Dairying}

THE report of the National Institute for Research in Dairying (University of Reading) for the year ended September 30, 1940, has just been published. Many members of the staff are now acting in an advisory capacity on various war-time committees appointed by the Government, especially the Ministry of Agriculture. The realization of the essential need for milk to balance the deficiencies of a war-time dietary and the multifarious problems that this involves is, of course, making demands on the work of the staff and thus a number of long-range research projects have been shelved in order that the staff may devote more time to advisory work and short-range investigations of war-time problems of the dairy industry. Details of the work of the various departments of the Institute, namely, dairy husbandry, chemistry, bacteriology, dairy bacteriology advisory, physiology and biochemistry, and of the experimental dairy are included in the report. Sixty-six research papers were published by various members of the staff during the year, and as usual a separate list of papers which can be supplied by the Librarian is appended. This latter list contains twenty-nine titles. The address of the Institute is Shinfield, near Reading, Berks.

\section{Country-Side}

THE first number of the war-time issue of CountrySide, the quarterly journal of the British Empire Naturalists' Association, has appeared to start the twelfth volume of this well-known journal. It is edited by Mr. Leslie Beckett, the honorary organizing secretary, and comprises a twenty-page octavo issue containing five original papers, a number of smaller notes and lists of regional field records on birds, insects and fungi. There is a list of twenty-one local branches of the British Empire Naturalists' Association (including a new one at Bath) which are remaining active during war-time. Mr. J. W. Bradley has a short article on the birds of Burma, Mr. E. L. Swann describes the formation of a Norfolk salt marsh and its subsequent flora, and Mr. M. B. B. Heath some recent observations of Mars. Among smaller notes there is an account of sotto voce song in the hen black. bird, the timing of the reeling song of the grasshopperwarbler to vary from 20 to 65 seconds with stops of 4-20 seconds between; Captain T. Dannreuther describes the immigration of clouded yellow butterflies to Great Britain in 1941. Mr. A. H. Wolley-Dod correlates the rarity of autumn bird song with the dry season, and there is a note on the abundance of privet hawk moth larvæ, even in London, this autumn. Field records include the wood-sandpiper, ruff, shelduck and gadwall at Cambridge sewage farm, the autumn passage of white wagtails in Lancashire, and October song of the blackbird in Wiltshire, where the speckled wood and comma butterflies were very numerous all the season.

\section{Horticultural History}

THREE papers in recent numbers of the Journal of the Royal Horticultural Society describe the history of gardens and gardeners of the past. The gardens at Wormley Bury, Broxbourne, Herts, have been the means of introducing many new plants to the horticulture of Britain. Sir Abraham and Lady Amelia Hume introduced many species between 1785 and 1825, including several notable Amaryllids, two species of Pronia, Rudbeckia pinnata and Humea elegans, named after the introducers. Major Albert Pam writes the article (66, Pt. 9, Sept., 1941), and is himself the present owner of Wormley Bury. The other two papers (66, Pts. 9 and 10, Sept. and Oct., 1941) are by the assistant secretary of the Society, and deal with the activities of William Forsyth in founding the Royal Horticultural Society. Forsyth's memory is maintained in the genus Forsythia which Vahl named in his honour', but he also experimented upon the treatment of wounded trees by covering the cut portions to exclude harmful fungi. He made useful contributions in this connexion, but clouded them so with extravagant claims that the benefit came to be largely discountenanced. 